\title{
Dividend Policy as a Corporate Communication and its Impact on Firm Value Evidences from listed companies in Qatar Stock Exchange
}

https://doi.org/10.21272/fmir.2(4).29--38.2018

Arindam Banerjee

Associate Professor, Amity University, Dubai

\begin{abstract}
Since decades, several theories have evolved on dividend decisions and their potential impact of firms overall wealth and performance that led to diverse results. These researches led to formulation of various financial theories and models that became applicable to the corporate world. Despite several research, the impact of dividend decisions on firm's share price and overall shareholders' wealth remains inconclusive. This paper aims towards establishing a relationship between of the impact of dividend policy decisions on firm's value taking a sample of 30 companies listed on the Qatar stock exchange (QE) which have been paying dividends for at least for five consecutive years. This study covered the time period from 2013-2017. Data have been taken on annual basis. Total number of observations in this study were 180. Data have been taken on annual basis. This study applied multiple regressions using E-Views or Minitab for the year 2017. Regression models have been developed to find the association between dividend policy and earnings per share (EPS), return on equity (ROE), and share price (SP).
\end{abstract}

Subjects: Corporate Finance, Financial Markets, Dividend Policy, Shareholder Wealth.

Keywords: dividend policy; shareholders wealth; firm performance; returns on equity; share price earning per share.

JEL Classification: G3, G32, G35, F65, D53.

(C) The Authors, 2018. This article is published with open access at Sumy State University.

Cite as: Ar. Banerjee. (2018). Dividend Policy as a Corporate Communication and its Impact on Firm Value Evidences from listed companies in Qatar Stock Exchange, Financial Markets, Institutions and Risks, 2(4), 29-38. https://doi.org/10.21272/fmir.2(4).29--38.2018

\section{About the Author}

Arindam Banerjee holds a Masters in Finance from the Institute of Chartered Financial Analysts of India and a Doctorate in Educational Leadership from UK. He has authored and edited more than ten books in finance and economics. For his research contributions, he has been awarded by Government of Dubai - Department of Economic Development, Dubai Financial Market and Emirates Islamic Bank.

\section{Public Interest Statement}

The primary objective of this research is to study the impact of dividend policy on shareholders' wealth and firm performance. This research applies multiple regression using E-Views for a period of 5 years from 20122017. A sample of 30 firms listed in Qatar stock exchange. The findings reveal that there exists a strong positive correlation between the dividend policy (in terms of dividend per share and dividend yield) and share price, a relatively positive correlation between dividend policy (in terms of dividend per share and dividend yield) and earnings per share return on equity. All this suggest towards a strong relevance of firms' dividend policy decisions. From this standpoint, though this paper is of serious academic research, it has profound implications for policy decisions of listed companies on Qatar stock exchange

\section{Introduction}

Over the years, firms' have traditionally engaged in profits maximisation. Though in more recent years, the focus has shifted towards the financial objective of shareholders' wealth maximisation. (Christopher Pass, Richard Dobbins, 1978). In the context of value maximization, corporate communications have always been crucially important to a firm as effective communications tends to increase firm value. (John C. Groth, 1988). One of the important modes of corporate communications has been a firm's dividend decision. Over the years, 
various scholars have looked into the importance of a firm's dividend policy mainly through two opposing models: the free cash-flow hypothesis and the signalling hypothesis. As argued, (Richard Fairchild, 2010) our understanding of dividend policy is limited by the lack of a model that integrates the two hypotheses. Despite several researches in the past five decades, 'dividend puzzle' is still unsolved. Empirical evidence done in this area is unclear and the search for the perfect answer for dividend policy continues. (N. Bhattacharyya, 2007). Irrespective of its ambiguity, the decision of paying dividends is still considered one of the most important and toughest that must be taken by a firm's management in alignment with its objectives, its future, and its value to the market. The decision balances off between two choices: the distribution of dividends to shareholders or the retention of the rest to be invested in new avenues in order to achieve more profits. (Abbadi et. al.2016).

\section{Literature review}

The dividend irrelevance theory was first formally presented by (Miller and Modigliani, 1961) where they pointed out the circumstances under which dividend policy does not affect the value of the firm. Since then, the argument over the impact of dividend policy on the value of the firm continues to this day. Their study showed that an investor can create any pattern of dividends desired regardless of the dividend pattern paid by the company. That is, the investor can convert any existing dividend stream into any desired consumption pattern, in the presence of Miller and Modigliani (M\&M) assumed perfect financial markets. Thus, the value of the firm is not determined by the pattern of the dividend stream but by the present value of the future dividends, regardless of the pattern. (Booth, L., \& Zhou, J. 2017) makes mention of Miller and Modigliani stating that they established the fact that in a "perfect" market, 'dividend irrelevance' argument holds, whereby a dividend payment or non-payment is identical in impact to changes in a firm's share structure. Consequently, the dividend payment itself is irrelevant to the value of the firm; what matters is the firm's free cash flow. In the real world, the institutional and financial structure of markets matters. Making a reference to the work of DeAngelo and DeAngelo (2006), (Magni, 2010) pointed that Miller and Modigliani's (1961) proof of dividend irrelevance was based on the premise that the amount of dividends distributed to shareholders is equal or greater than the free cash flow generated by the fixed investment policy. The researchers claimed that if retention is allowed, dividend policy is not irrelevant. In contrast, (Magni, 2010) argued that the dividend irrelevance proposition holds even in case of retention. The key assumption did not pertain to retention but with the NPV of the extra funds and if NPV was zero, dividend irrelevance would apply.

Studies on the impact of dividend policy on stock price can be dated back to (Walter, 1956), where he discussed how stock prices is influenced by dividend policies. His analysis was based on the assumption that share price is the present value of dividends investors expect to receive over an extended period of time. Within this framework stocks that pay no dividend now have value in the form of dividends expected to be paid in the future. In his paper, he used a capitalization rate to value dividends, and discussed valuation for three separate kinds of securities--growth stocks, intermediate stocks, and creditor stocks, which in some ways resemble debt securities. (Gejalakshmi, et. al. 2017) opines that dividend is the key determinant of share price and firm's value. The optimal dividend policy is the one that maximizes the firm's stock price which leads to shareholders' wealth maximization thus safeguards rapid economic growth in the country. The corporate growth makes it ultimately possible to get more dividends. Their study of the long-run relationship between the dividend policy and the shareholders' wealth in consumer non-cyclical sector in India established a stationary, long- run co-integration between the two. (Khanum, 2013) discusses the importance of information content in dividend policy. The research discussed the influence of dividend decisions on stock market reaction and shareholder wealth. In some of the recent studies such as, (Akhigbe, 1996), citations can be found that addresses the question of whether dividend policy signal future changes in the expected future cash flows of firms and thus its value.

Starting from the seminal paper of (Walter, 1963), dividend policy as a corporate finance activity has been at the centre of academic research. His paper, pointed out the influence of dividend policy and on the value of the business enterprise. Irrespective of whether capitalists and financiers consider dividends more important than retained earnings at the margin is studied through examining net cash flows from operations. The impact of additions to and subtractions to net cash flows upon stock values are explored in the paper. Net cash flows from operations can be collected from the payment of interest on debt or its equivalent as well as capital investments and dividends. Later research by (Frost, 1978) presented evidences indicating that investors place a higher value on a dollar of dividends than on a dollar of capital gains. Their result, had important implications 
for corporate dividend policy and raised questions about the practicality of the popular capital asset pricing model (CAPM), which assumes dividend irrelevancy policy

(Travios, 2001) presented a study examined the stock in Cyprus stock market between the period of 1985 and 1995 and found a positive impact of cash and stock dividend on the share price. (Abeyratna Gunasekarage, et. al. 2006) studied that at the time of dividend announcements, share returns tend to be positive where companies have increased and negative where companies have decreased the dividend and earnings. Their studies also reveal evidence to suggest that the stock market anticipates part of this news in the preceding twelve months. Though, the dividend/earnings news does not appear to act as a signal of long-term future company performance; companies which reduce this dividend and reported lower earnings realized the largest excess returns over the next five years. Results shown by (Zhang, 2007) pointed that shareholders of noncirculating Chinese stock get a high return rate by cash dividends, and circulating shareholders obtain a high short-term return rate by stock dividends. Studies done by (Apostolos Dasilas, et. al 2009) shows that dividend initiations result about significant positive abnormal returns in the announcement period. The impact of dividend on share price is inversely associated with the information environment. (Hussainey, 2011) studies the relevancy of dividend policy in corporate decision making is in determining share price changes for a sample of firms listed in the London Stock Exchange. They examined the relation between dividend policy and share price changes in the UK stock market and found a positive relation is found between dividend yield and stock price changes, and a negative relation between dividend payout ratio and stock price changes. With respect to country specific context, (Campbell and Ohuocha 2011) suggested that companies that chose their own announcement date outside the Nigerian stock exchange announcement window experience positive abnormal returns if their stock is more frequently traded and negative abnormal returns if their stock is less frequently traded. (Goel, S. 2015) looks at the dividend policy of the top Indian companies with respect to its consistency and its effect on their market price. Their study analyzes the interrelationship between corporate dividend policy and its market value of listed companies for a period of five years, from 2006 to 2010. Their results found a linear relationship between dividend decision and market price of the companies but for a limited duration following which the market starts behaving efficiently and absorbs the available information. (Ajayi, 2015) went on to study that dividend policy impacts the share price movement and its volatility as important parameters to investors as the lesser the volatility of a given share, the greater the propensity of investors to have them. Their study examined the effect of dividend policy on share price volatility of firms in the Nigerian banking industry. Their result shows a positive relationship between dividend payout ratio and share price volatility for dividend paying firms, and a negative relationship between retention ratio and share price volatility for lesser dividend paying firms. The study suggested that declaration of dividend by Nigerian banks caused more volatility in share price movement while retained earnings causes less volatility in share price movement of banks in Nigeria. (Abbadi et. al. 2016) revealed the existence of a statistically significant effect of the dividends policies on the Jordanian industrial companies' stock price. In their research article, (Ozuomba. 2016) examined the effect of dividend policies on shareholders wealth of public companies in Nigeria. The study revealed the relevance of dividend policy and further proved that dividend policies of public limited companies influenced the wealth of shareholders in Nigeria. In a similar study, (Ofori et. al. 2017) studied the impact of dividend policy on shareholder value of listed companies in Ghana. Using data from 2009 to 2014 listed companies on the Ghana Stock Exchange, the study found a positive relationship between dividend per share and shareholders' value. Additionally, it was found that firms with higher dividend yield had the likelihood to reduce shareholders' value, as confirmed by a negative and significant correlation between dividend yield and shareholders' value. It concludes that dividend policy has a strong relationship with shareholders' value, thus recommending that managers should embark on prudent investment activities that would generate higher returns to shareholders in order to increase shareholder value. In his study on the relationship between a company's market value and its dividend policy, both cash and stock, (Emeni, 2017) on a set 142 companies listed on the Nigerian Stock Exchange (NSE) for the financial year 2002 to 2011, revealed that (a) cash dividend and investment policy have a negative but significant relationship with the market value of companies listed on the NSE and (b) stock dividend and earnings have a positive and significant relationship with market value of companies listed on the NSE. Similar revelations were made by (Uwuigbe, 2012)

In contrast, (Areri et. al. 2018) argues that the recent financial crisis shows that excessive dividends lead to financial distress. In their study, (Varghese 2017) explored to study is an attempt to find out the extent of the influence of dividend payout on shareholders' wealth and whether market value of common stock has strong correlation with cash dividend paid or with the growth in earning per share. Their results concluded that in the IT sector, five predictor variables - earnings per share, lead price earnings ratio, lagged price earnings 
ratio, price earnings ratio and retained earnings ratio have a significant positive effect on shareholder's wealth while dividend per share has a significant negative effect. This indicated that dividend per share does not strongly affect the shareholder's wealth. From their studies of the share price from eight most popular companies in India (Farhat, 2015) concluded that dividend policy does not affect the price of the share.

Thus, as it can be observed from the academic literatures, the impact of dividend policy on shareholders wealth still remains unresolved. The decision of dividend policy has been one of the most questionable issues in corporate finance literature. Several researchers have tried to reveal issues pertaining to dividend policy, however, we still don't have a reliable explanation on the behavior of dividend policy. In their study of the impact of dividend policy on shareholders' wealth and firm performance in Pakistan (Farrukh, K., et.al. 2017), they found out that dividend policy has positively significant impact on shareholders' wealth and firm performance.

\section{Doha Securities Market (DSM)}

Doha Securities Market (DSM) was established in 1995, but officially started operations in 1997. Since then the exchange grew to become one of the leading stock markets in the GCC region. In June 2009, Qatar Holding, the strategic and direct investment arm of Qatar Investment Authority (QIA), and NYSE Euronext, the world's leading exchange group, signed an agreement to form a major strategic partnership to create the Exchange as a world-class market. Post the deal, DSM was renamed the Qatar Stock Exchange. DSM aims to support Qatar's economy by providing a platform for capital raising for Qatari companies as part of their corporate strategy and giving investors an avenue through which they can trade a variety of products in a transparent and efficient manner. The exchange also provides the public with access to market information and ensures correct disclosure of information.

\section{Problem statement}

Despite several research done on the subject, the impact of dividend policy on shareholders wealth still remains a puzzle. Results of various studies have revealed significant differences across countries, thus leaving a bigger space to explore this issue in different countries. Keeping this in mind, this paper explores the uncertainty in relation between dividend policy \& shareholders wealth (earning per share, return on equity) $\&$ firm performance (share price) is important matter of study for analyzing.

\section{Study objectives}

The objectives of this research are to explore the extent of correlation between dividend policy and shareholders' wealth measured in terms of share market price, earning per share, and return on equity.

On the basis of reviewed literature, following hypotheses have been developed.

H0: There is no significant association between dividend policy and market price of share

H1: There is a significant association between dividend policy and market price of share

$\mathrm{H} 0$ : There is no significant association between dividend policy and return on equity

H1: There is a significant association between dividend policy and return on equity

H0: There is no significant association between dividend policy and earning per share.

$\mathrm{H} 1$ : There is a significant association between dividend policy and earning per share.

\section{Methodology}

A sample of 30 firms listed in Qatar stock exchange has been selected by including the firms which have been paying dividends for at least for five consecutive years. This study covered the time period for the period 2013-2017. Data have been taken on annual basis. This study applied multiple regressions using E-Views or Minitab for the year 2017.

\section{Study model}

To find the association between dividend policy, EPS, ROE, SP, the following models have been developed:

In this model, share price is the dependent variable and dividend policy is used as independent variable. Two proxies (dividend per share and dividend yield) are used to measure dividend policy. 
$d(S P)_{i, t}=\beta_{0}+\beta_{1} d(D P S)_{i, t}+\beta_{2} D Y_{i, t}+e_{i, t}$

In this model, earning per share is the dependent variable and dividend per share and dividend yield are used to measure dividend policy.

$E P S_{i, t}=\beta_{0}+\beta_{1} d(D P S) i, t+\beta_{2} D Y i, t+e_{i, t}$

In this model, return on equity is the dependent variable and dividend per share and dividend yield are used to measure dividend policy.

$d(R O E)_{i, t}=\beta_{0}+\beta_{1} d(D P S)_{i, t}+\beta 2 D Y_{i, t}+e_{i, t t}$

\section{Data collection}

Descriptive statistics. Table 1 presents the summary of descriptive statistics. For earning per share, the mean value and its standard deviation in firms listed are 4.52 and 4.24. These two values demonstrate the panel data dispersion. The findings of mean value and standard deviation imply there is dispersion of earning per share in the sample firms. For return on equity, the mean value and its standard deviation in firms are 10.85 and 7.47. For share price, the mean value and its standard deviation are 55.91 and 46.13 whereas the median is 39.85. For dividend per share, mean value, median, and its standard deviation are 4.07, 4, and 2.25 respectively. However, the highest value for the dividend per share is 6.67 per share and the lowest value recorded is -0.09. It shows -1 when company is borrowing money from bank to pay dividend to shareholders. Mean, median, and standard deviation of dividend yield are 2.92, 2.93, and 2.17, respectively.

Table 1. Descriptive statistic

\begin{tabular}{|l|c|c|c|c|c|}
\hline & Mean & Median & Maximum & Minimum & Std. dev. \\
\hline EPS & 4.52 & 3.42 & 14.69 & -0.09 & 4.24 \\
\hline ROE & 10.85 & 12.72 & 33.58 & -0.38 & 7.47 \\
\hline SP & 55.91 & 39.85 & 197.00 & 0.5 & 46.13 \\
\hline DY & 2.92 & 2.93 & 6.67 & -0.09 & 2.17 \\
\hline DPS & 4.07 & 4.00 & 8.50 & 0.04 & 2.25 \\
\hline
\end{tabular}

Source: Prepared by the author.

Table 2 shows correlation coefficients of variables of the study. The value of correlation coefficient between two independent variables is $49 \%$

Table 2. Correlation analysis

\begin{tabular}{|l|l|c|c|c|c|}
\hline & EPS & ROE & SP & DY & DPS \\
\hline EPS & 1.00 & & & & \\
\hline ROE & 0.55 & 1.00 & & & \\
\hline SP & 0.85 & 0.34 & 1.00 & & \\
\hline DY & 0.65 & 0.39 & 0.53 & 1.00 & \\
\hline DPS & 0.66 & 0.31 & 0.72 & 0.49 & 1.00 \\
\hline
\end{tabular}

\begin{tabular}{|l|l|}
\hline EPS & Earnings per share \\
\hline ROE & Return on Equity \\
\hline SP & Share price \\
\hline DY & Dividend Yield \\
\hline DPS & Dividend per share \\
\hline
\end{tabular}

Source: Prepared by the author.

\section{Model selection}

In order to select the appropriate model, redundant fixed effect test has been applied to finalize the suitable model between common constant model and fixed effect model. The selection of the appropriate model (common constant or fixed effect) depends on the acceptance or rejection of null hypothesis of redundant fixed effect test. If null hypothesis of the redundant fixed effect test is not accepted then it is determined that fixed effect model is appropriate model. Whereas on acceptance of null hypothesis of redundant fixed effect test, we further apply another test named Breusch- Pagan test. The Breusch-Pagan test then decides the appropriate model between common constant and random effect model. Rejection of its null hypothesis suggested that random effect model is a suitable model but if the Breusch-pagen test also endorsed the common constant model then the final available option is common constant model. In this study, redundant fixed effect test and then Breusch-Pagan test have been applied on the panel data; and the acceptance of null hypothesis of both redundant fixed effect test and Breusch-pagen test indicate that common constant model is appropriate to explain the relationship between the proposed variables under consideration. 
As indicated in the following Table 3, the probability value shows the acceptance of null hypothesis of both redundant fixed effect test and Breusch-pagen test. It indicates that common constant model is appropriate to explain the relationship between the three proposed models. Common constant model interrogates the relationship between predictors and the explained variables without an entity. In common constant model, all individuals have a common slope, but different intercepts. The basic purpose of the fixed effect model is to segregate the individual effect. The results of common constant model are shown in Tables 3, 4 and 5

Table 3. The acceptance of null hypothesis of both redundant fixed effect test and Breusch-pagen test

\begin{tabular}{|l|c|c|c|}
\hline \multicolumn{1}{|c|}{ Probability values } & & & Status \\
\hline Test & Relations & Prob. & Common constant model \\
\hline Redundant fixed effect/F-test & DP-SP & 1 & Common constant model \\
\hline Redundant fixed effect/F-test & DP-EPS & 1 & Common constant model \\
\hline Redundant fixed effect/F-test & DP-ROE & 1 & 1 \\
\hline
\end{tabular}

Source: Prepared by the author.

\section{Findings}

Table 4 shows the results of regression for price per share. It demonstrates that for each unit increase in dividend per share, the share price will increase by 12.47 units, and for each unit increase in dividend yield, the share price will increase by 4.94 units.

Table 4. Dependent variable d(SP)*

\begin{tabular}{|l|c|c|c|c|}
\hline \multicolumn{1}{|c|}{ Variable } & Coefficient & Std. error & t-statistic & Prob. \\
\hline C & -9.2936286 & 12.4730893 & -0.74509437 & 0.462651752 \\
\hline d(DPS) & 12.4714677 & 2.99404887 & 4.16541889 & 0.000285333 \\
\hline DY & 4.93679073 & 3.10866284 & 1.58807532 & 0.123912442 \\
\hline
\end{tabular}

Source: Prepared by the author.

Table 5 shows the results of regression for price per share. It illustrates that for each unit increase in dividend per share, the earning per share will increase by 0.85 units, whereas for each unit increase in dividend yield, the earning per share will increase by 0.83 unit.

Table 5. Dependent variable EPS*

\begin{tabular}{|l|c|c|c|c|}
\hline Variable & Coefficient & Std. error & t-statistic & Prob. \\
\hline C & -1.3579492 & 1.13570559 & -1.19568767 & 0.242214494 \\
\hline d(DPS) & 0.84778315 & 0.27261554 & 3.10981223 & 0.004382185 \\
\hline DY & 0.82890443 & 0.28305143 & 2.92845874 & 0.006842026 \\
\hline
\end{tabular}

Source: Prepared by the author.

Table 6 exhibits that one unit increase in dividend per share brings 0.52 unit increase in return on equity, where as one unit increase in dividend yield will increase return on equity by 1.08 units. So Tables 3,4 and 5 show the results of regression and indicate the relationship among dependent and independent variables. Most of the relationships are positive except for SP \& ROE with respect to dividend yield.

Table 6. Dependent variable d(ROE)*

\begin{tabular}{|l|c|c|c|c|}
\hline Variable & Coefficient & Std. error & t-statistic & Prob. \\
\hline C & 5.55954423 & 2.7799392 & 1.9998798 & 0.055666165 \\
\hline d(DPS) & 0.52084814 & 0.6672985 & 0.78053246 & 0.441867272 \\
\hline DY & 1.08580964 & 0.69284309 & 1.56717972 & 0.128719251 \\
\hline
\end{tabular}

Source: Prepared by the author.

\section{Future Implications}

Since decades, several theories have evolved on dividend decisions and their potential impact of firms overall wealth and performance that led to diverse results. These researches led to formulation of various financial theories and models that became applicable to the corporate world. From this standpoint, though this paper is of serious academic research, it has profound implications for policy decisions of listed companies on Qatar stock exchange. Further, though there have been several researches on the topic but research on companies listed on Qatar stock exchange are next to none, thus this paper becomes significantly important for further research for companies listed on QE. 


\section{Observations \& conclusion}

On the basis of redundant fixed effect test, we decided that common constant model is an appropriate model. We came to know from the probability of redundant fixed effect test which is 1 in all three equations. It means we have to accept null hypothesis which shows common constant method is more appropriate. So, we estimate regression with common constant effect model to measure the influence of dividend policy on firm performance.

The results report that there is a significantly positive relationship between return on equity and dividend policy. It means that increase in dividend payment has a positive impact on firm performance. But many of the studies show significantly negative relationship between dividend payout and firm profitability. The negative relation means that when companies pay dividend, it affects the retained earning which reduces the firms internal earnings.

The results report that there is a positive association between share price and the dividend policy.

Results also show that there is a positive relationship between earning per share and the dividend policy. It means when dividends payment increases, it upsurges the shareholders wealth (EPS).

Therefore, the regression results of all these models show almost positively significant result between firm's dividend policy and EPS, ROE, SP. Regression results state that dividend policy is positively linked with earning per share and share price. Moreover, dividend policy is also significantly positively associated with return on equity.

\section{References}

1. Abeyratna Gunasekarage, David M. Power. (2006). Anomalous evidence in dividend announcement effect", Managerial Finance, 32(3), pp.209-226, https://doi.org/10.1108/03074350610646726

2. Ajayi M, Seyingbo O. Dividend Policy and Share Price Volatility in Nigerian Banking Industry. Fountain Journal of Management \& Social Sciences (FUJMAS) [serial online]. January 2015; 4(1):1-10. Available from: Business Source Complete, Ipswich, MA. Accessed May 13, 2018.

3. Akhigbe, A., \& Madura, J. (1996). Dividend policy and corporate performance. Journal of Business Finance \& Accounting, 23(9/10), 1267-1287.

4. Al Abbadi, A. A., Al-Amarneh, A., \& Abuorabi, M. M. (2016). The Impact of the Dividend Policies on the Value of the Stock of Public Shareholding Companies in the Jordanian Industrial Sector. International Management Review, 12(2), 29-36.

5. Apostolos Dasilas, Katerina Lyroudi, Demetrios Ginoglou, (2009). The impact of dividend initiations on Greek listed firms' wealth and volatility across information environments, Managerial Finance, 35(6).

6. Areri, B. J., \& Nyang'. Au, V. N. (2018). An Evaluation of Determinants of Dividend Policy A Study of The Banking Sector in Kenya. Clear International Journal of Research in Commerce \& Management, 9(3), 19-22.

7. Booth, L., \& Zhou, J. (2017). Dividend policy: A selective review of results from around the world. Global Finance Journal, 341-15. doi:10.1016/j.gfj.2017.07.002

8. Christopher Pass, Richard Dobbins, (1978). Financial Objectives: The Traditional Approach, Managerial Finance, 4(1), pp.2-9, https://doi.org/10.1108/eb013409

9. Emeni, F. K. (2017). The Effect of Dividend Policy on Market Value of Firms: Evidence from Nigeria. Finance India, 31(1), 175-208.

10. Farhat. (2015). Relationship Between Dividend Policy and Share Price. Clear International Journal of Research in Commerce \& Management, 6(8), 35-40.

11. Farrukh, K., Irshad, S., Shams Khakwani, M., Ishaque, S., \& Ansari, N. (2017). Impact of dividend policy on shareholders wealth and firm performance in Pakistan. Cogent Business \& Management, 4(1), 1-11. https://doi.10.1080/23311975.2017.1408208

12. Frost, P. A. (1978). Dividend Policy and Capital Market Theory: A Comment. Review of Economics \& Statistics, 60(3), 475.

13. Gejalakshmi, S., \& Azhagaiah, R. (2017). Impact of Dividend Policy on Shareholders' Wealth: Indian Scene. SCMS Journal of Indian Management, 14(2), 28-45.

14. Goel, S. (2015). Dividend Policy and Market Price Behaviour in Indian Companies. Skyline Business Journal, 11(1), 46-52. 
15. Hussainey, K., Mgbame, C. O., \& Chijoke-Mgbame, A. M. (2011). Dividend policy and share price volatility: UK evidence. Journal of Risk Finance (Emerald Group Publishing Limited), 12(1), 57-68. doi: $10.1108 / 15265941111100076$

16. John C. Groth, (1988). Corporate Communications and firm Value", Managerial Finance, 14(1), pp.1-5, https://doi.org/10.1108/eb013590

17. Kevin Campbell, Chijioke Ohuocha, (2011). The stock market reaction to stock dividends in Nigeria and their information content, Managerial Finance, 37(3), pp.295-311, https://doi.org/10.1108/ $\underline{03074351111113333}$

18. Khanum, A. (2013). A Note on the Information Content of Corporate Dividend Policy. Lahore Journal of Business, 2(1), 133-146.

19. Magni, C. A. (2010). Relevance or Irrelevance of Retention for Dividend Policy Irrelevance. International Review of Applied Financial Issues \& Economics, 2(2), 232-247.

20. McGowan Jr., C. B. (2005). A simplified approach to demonstrating the irrelevance of dividend policy to the value of the firm. Applied Financial Economics Letters, 1(2), 121-124. doi:10.1080/17446540500080032

21. M. C., M., \& Varghese, D. (2017). Effect of Dividend Policy on Share Holder's Wealth: A Study of IT and Banking Industry in India. Finance India, 31(2), 535-544.

22. N. Bhattacharyya, (2007) "Dividend policy: a review", Managerial Finance, 33(1), pp.4-13, https://doi.org/10.1108/03074350710715773

23. Ofori-Sasu, D., Abor, J. Y., \& Osei, A. K. (2017). Dividend Policy and Shareholders' Value: Evidence from Listed Companies in Ghana. African Development Review, 29(2), 293-304. doi:10.1111/14678268.12257

24. Ozuomba, C., Anichebe, A., \& Okoye, P. (2016). The effect of dividend policies on wealth maximization - a study of some selected plcs. Cogent Business \& Management, 3(1), 1-15. doi:10.1080/ 23311975.2016.1226457

25. Richard Fairchild, (2010). Dividend policy, signalling and free cash flow: an integrated approach", Managerial Finance, 36(5), pp.394-413, https://doi.org/10.1108/03074351011039427

26. Travios, N., Trigeorgis, L., \& Vafeas, N. (2001). Shareholder Wealth Effects of Dividend Policy Changes in an Emerging Stock Market: The Case of Cyprus. Multinational Finance Journal, 5(2), 87.

27. Uwuigbe, U., Jafaru, J., \& Ajayi, A. (2012). Dividend Policy and Firm Performance: A Study of Listed Firms in Nigeria. Accounting \& Management Information Systems / Contabilitate Si Informatica De Gestiune, 11(3), 442-454.

28. WALTER, J. E. (1956). Dividend Policies and Common Stock Prices. Journal of Finance, 11(1), 29-41.

29. Walter, J. E. (1963). Dividend Policy: It's Influence on The Value of The Enterprise. Journal of Finance, $18(2), 280-291$.

30. Yi, Y., Ke, D., \& Zhang, X. (2007). Shareholder wealth effect of dividend policy: Empirical evidence from the Chinese securities market. Frontiers of Business Research in China (Springer Science \& Business Media B.V.), 1(3), 437-455. doi:10.1007/s11782-007-0026-8 


\section{Appendix}

Table 6. Summary output - Share Price (SP)

\begin{tabular}{|c|c|c|c|c|c|c|c|c|}
\hline \multicolumn{2}{|c|}{ Regression Statistics } & & & & & & & \\
\hline Multiple R & 0.7502776 & & & & & & & \\
\hline R Square & 0.56291647 & & & & & & & \\
\hline Adjusted R Square & 0.53053991 & & & & & & & \\
\hline Standard Error & 31.604286 & & & & & & & \\
\hline Observations & 30 & & & & & & & \\
\hline \multicolumn{9}{|l|}{ ANOVA } \\
\hline & $d f$ & $S S$ & $M S$ & $F$ & Significance $F$ & & & \\
\hline Regression & 2 & 34732.43604 & 17366.22 & 17.38654 & $1.40482 \mathrm{E}-05$ & & & \\
\hline Residual & 27 & 26968.43411 & 998.8309 & & & & & \\
\hline \multirow[t]{2}{*}{ Total } & 29 & 61700.87015 & & & & & & \\
\hline & Coefficients & Standard Error & $t$ Stat & $P$-value & Lower $95 \%$ & Upper 95\% & Lower $95.0 \%$ & Upper $95.0 \%$ \\
\hline Intercept & -9.29362862 & 12.47308929 & -0.74509 & 0.462652 & -34.88629386 & 16.29903661 & -34.88629386 & 16.29903661 \\
\hline X Variable 1 & 12.4714677 & 2.994048869 & 4.165419 & 0.000285 & 6.328186892 & 18.61474857 & 6.328186892 & 18.61474857 \\
\hline$X$ Variable 2 & 4.93679073 & 3.108662838 & 1.588075 & 0.123912 & -1.441658544 & 11.31524001 & -1.441658544 & 11.31524001 \\
\hline
\end{tabular}

Source: Prepared by the author.

\begin{tabular}{|c|c|c|c|c|c|c|c|c|}
\hline \multicolumn{9}{|l|}{ Regression Statistics } \\
\hline Multiple R & 0.755291699 & & & & & & & \\
\hline R Square & 0.57046555 & & & & & & & \\
\hline Adjusted R Square & 0.538648184 & & & & & & & \\
\hline Standard Error & 2.877648302 & & & & & & & \\
\hline Observations & 30 & & & & & & & \\
\hline \multicolumn{9}{|l|}{ ANOVA } \\
\hline & $d f$ & $S S$ & $M S$ & $F$ & Significance F & & & \\
\hline Regression & 2 & 296.9413068 & 148.4707 & 17.92938 & $1.11038 \mathrm{E}-05$ & & & \\
\hline Residual & 27 & 223.5832132 & 8.28086 & & & & & \\
\hline \multirow[t]{2}{*}{ Total } & 29 & 520.52452 & & & & & & \\
\hline & Coefficients & Standard Frror & $t$ Stat & $P$-value & Lower $95 \%$ & Unner $95 \%$ & Lower $950^{\circ}$ & Unper $950^{\circ}$ \\
\hline Intercept & -1.357949167 & 1.135705588 & -1.19569 & 0.242214 & -3.688224551 & 0.972326217 & -3.688224551 & 0.972326217 \\
\hline $\mathrm{X}$ Variable 1 & 0.847783154 & 0.272615545 & 3.109812 & 0.004382 & 0.28842226 & 1.407144048 & 0.28842226 & 1.407144048 \\
\hline X Variable 2 & 0.828904434 & 0.28305143 & 2.928459 & 0.006842 & 0.248130873 & 1.409677996 & 0.248130873 & 1.409677996 \\
\hline
\end{tabular}

Source: Prepared by the author

Table 8. Summary output - ROE

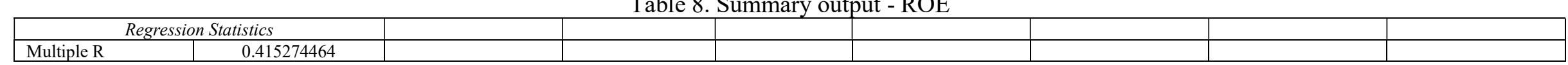


Table 8 (cont.). Summary output - ROE

\begin{tabular}{|c|c|c|c|c|c|c|c|c|}
\hline R Square & 0.172452881 & & & & & & & \\
\hline Adjusted R Square & 0.111153094 & & & & & & & \\
\hline R Square & 0.172452881 & & & & & & & \\
\hline Adjusted R Square & 0.111153094 & & & & & & & \\
\hline Standard Error & 7.043803776 & & & & & & & \\
\hline Observations & 30 & & & & & & & \\
\hline \multirow{2}{*}{\multicolumn{9}{|c|}{ ANOVA }} \\
\hline & $d f$ & $S S$ & $M S$ & $F$ & Siomifo of & & & \\
\hline Regression & 2 & 279.161796 & 139.5809 & 2.81327 & 0.077660802 & & & \\
\hline Residual & 27 & 1339.609634 & 49.61517 & & & & & \\
\hline \multirow[t]{2}{*}{ Total } & 29 & 1618.77143 & & & & & & \\
\hline & Coefficionts & Standard Frror & Stat & $P_{-}$yalue & $I 040050 \%$ & $5=050$ & $T=050^{\circ}$ & $S T=050^{0} \lambda$ \\
\hline Intercept & 5.559544232 & 2.779939197 & 1.99988 & 0.055666 & -0.144419846 & 11.26350831 & -0.144419846 & 11.26350831 \\
\hline X Variable 1 & 0.52084814 & 0.667298503 & 0.780532 & 0.441867 & -0.848335292 & 1.890031572 & -0.848335292 & 1.890031572 \\
\hline X Variable 2 & 1.085809637 & 0.692843086 & 1.56718 & 0.128719 & -0.33578695 & 2.507406223 & -0.33578695 & 2.507406223 \\
\hline
\end{tabular}

Source: Prepared by the author. 